\title{
Glant, Tibor, ed. 2020. Az Egyesült Államok útja Trianonhoz: Az Inquiry és Magyarország jövöje, 1917-1918, Források ('The Approach of the United States to Trianon: The Role of "Inquiry" in Defining Hungary's Future, 1917-1918, Sources'). Trans. Gergely Máté Balogh Budapest: Bölcsészettudományi kutatóközpont, történettudományi intézet: 1-272.
}

\author{
Reviewed by Andrew Ludányi, Emeritus Professor of Political Science and History, Ohio \\ Northern University a-ludanyi@onu.edu
}

On the one-hundredth anniversary of the Treaty of Trianon many interesting studies and analyses have been published about the causes and consequences of this peace-making travesty. Tibor Glant's approach has been to focus on the preparations of the United States to establish a new order following World War I. His book is a compilation and analysis of the work of the "Inquiry" established by Colonel Edward M. House on instructions from President Woodrow Wilson in a letter dated September 2, 1917, just five months after the United States entered the war on the side of the Entente. Unlike many previous studies and compilations of the Inquiry's work, Glant concentrates on those documents and position papers which had the Kingdom of Hungary in their crosshairs.

In compiling these documents, Tibor Glant has a double objective. The first is to provide an explanation for the one-sided results of the treaty-making process and, second, to demolish three myths that have surrounded American participation at Versailles. Before we reflect on these questions, the book's organization and characteristics deserve our attention. Within the context of 272 pages it provides the reader with the key documents that related to historical Hungary as part of the Austro-Hungarian Dual Monarchy. These documents are preceded by the editor's introductory essay about the organization, the perspectives, and the backgrounds of the academicians and diplomats who were the formulators of American policy. This systematic introductory essay is backed up by ninety-four effective scholarly footnotes, a listing of the archival location of the sources at the major sites and the extensive bibliography that the editor utilized. The volume also contains both a name index of persons and the places that appear in the documents and the analysis. This is supplemented by four photographs of key players of the peace-making drama and six maps that are linked to the proposed border changes.

American preparations for peace-making were all orchestrated through the Inquiry. This organization, perhaps the first American foreign policy "think tank," was named by James T. Shotwell of Columbia University to obfuscate the objective of the organization toward the outside world. According to Lawrence E. Gelfand, the best authority on the Inquiry, of the 126

(cc) BY

ULLS D-Serle 
Ludányi, Andrew. "Glant, Tibor, ed. 2020. Az Egyesült Államok útja Trianonhoz: Az Inquiry és Magyarország jövöje, 1917-1918, Források ('The Approach of the United States to Trianon: The Role of "Inquiry" in Defining Hungary's Future, 1917-1918, Sources'). Trans. Gergely Máté Balogh Budapest: Bölcsészettudományi kutatóközpont, történettudományi intézet: 1-272.” Hungarian Cultural Studies. e-Journal of the American Hungarian Educators Association, Volume 14 (2021) DOI: 10.5195/ahea.2021.450

appointed members of the organization only eleven dealt with the fate of the Austro-Hungarian Monarchy. These academicians were mainly from Ivy League universities like Yale, Princeton, Harvard and Columbia, with a few from places like the University of Chicago and the University of Missouri. Most of their meetings and work sessions took place in New York City. The Inquiry was not attached to the State Department, but reported to the President directly through Colonel House. It was supposed to come up with the proposals that were to guide the decisions of the American delegation at the conference in France. The proposals were to include the foundations of a new international order based on the objectives outlined and later amended in Wilson's Fourteen Points. The new order was to "make the world safe for democracy" by securing the "self-determination of peoples" and ending the curse of "secret treaties." All this was to be achieved under the guardianship of a new international umbrella organization called the League of Nations.

As some observers have pointed out, Wilson's Fourteen Points of January 8, 1918, was a response to Nikolai Lenin's war aims announcement of November 8, 1917, which opened the door to the separate peace signed at Brest Litovsk. The linkage is important, since Czarist Russia's collapse and departure from the battlefield created new circumstances that had to be addressed by the Entente.

From the beginning the objectivity of the Inquiry was undermined by formulating their proposals from the perspective and interests solely of the victors. This, in spite of the fact that Wilson claimed that the United States did not have an ax to grind and could therefore be a more disinterested peace-maker than its allies. However, as Tibor Glant points out, the Fourteen Points and American war aims were already in place by the time the Inquiry began its work in earnest. Furthermore, the Inquiry only switched to formulating the American position on boundaries after July-August, 1918. Yet, the American position was by that time committed to the dissolution of the Austro-Hungarian Monarchy. Perhaps this was inevitable, once the Inquiry's composition excluded anyone who had any affiliation with the defeated Central Powers, except for the Armenian-Ottoman Leon Dominian. The Inquiry did not have any specialists who knew Hungarian, although they could have turned to American Hungarian publicists, librarians and historians like Géza Kende, Alexander Kontra or Charles Feleky. On the other hand, they depended on the partisan Czech American, Robert J. Kerner and the partisan Romanian American, Max Handman.

The deck was also stacked against historic Hungary by the chaos that ruled in Hungary as the front collapsed. The assassination of István Tisza, the wartime Prime Minister, was followed by weak or indecisive and opportunistic leaders who were incapable of mobilizing the Hungarian nation. Furthermore, the decision to rapidly disarm eliminated the only institution that could have provided order and defense against the territorial appetites of the French supported neighbors. On top of all this, the leadership vacuum led to the power seizure in March, 1919 of Béla Kun and the Communists who wanted to link up with Lenin's Revolutionary forces in Russia. This provided an additional pretext for the Entente to justify weakening and isolating Hungary.

While France under Georges Clemenceau already was commited to the break-up of the Austro-Hungarian Monarchy in 1915, the British joined them when they signed secret treaties with Italy and Romania during 1915 and 1916, respectively. Woodrow Wilson moved in this direction only in August-September of 1918. The Inquiry at that time no longer produced 
Ludányi, Andrew. "Glant, Tibor, ed. 2020. Az Egyesült Államok útja Trianonhoz: Az Inquiry és Magyarország jövöje, 1917-1918, Források ('The Approach of the United States to Trianon: The Role of "Inquiry" in Defining Hungary’s Future, 1917-1918, Sources'). Trans. Gergely Máté Balogh Budapest: Bölcsészettudományi kutatóközpont, történettudományi intézet: 1-272." Hungarian Cultural Studies. e-Journal of the American Hungarian Educators Association, Volume 14 (2021) DOI: 10.5195/ahea.2021.450

background studies and focused just on what the new borders would look like after the Monarchy was dissolved. These Inquiry proposals were summarized in the one-hundred page Black Book that the American delagates took with them to Paris, with the intent of providing a "just" and "achievable" break-up of the Monarchy. An abbreviated summary of eleven pages was also provided and named the Red Book because of its red cover. Unlike the French and British architects of the dictated peace terms, the United States joined the process with a commitment to keep ethnic/nationality affiliation as the most important guide in determining borders.

This was not to be! Among the reasons was Italy's tunnel vision regarding the objectives it wanted to achieve at the conference. Vittorio Orlando went along with almost everything that the French and British powers put on the table as long as Italy's desired goals were assured regarding the control of South Tyrol, Trieste, Fiume and Italian dominance of the Adriatic Sea and Albania. The Americans were similarly "paid off" by the French and British by having Wilson's baby, the League of Nations and its Covenant, put in the forefront on all the treaty documents. (This took place while Wilson went back to the USA to sell the results to the public.) On his return to Paris, he lost interest in the rest of the treaty-making process. This meant that the nationality "self determination" principle could be sacrificed for the French and British geopolitical interests. For the British Empire this meant mainly control of the Suez Canal and of the "liberated" Arab areas of the collapsed Ottoman Empire. This assured them of access to the oil fields around the Persian/Arab Gulf and the denial of German access via the pre-war construction of the Berlin to Baghdad railway. The French supported this part of British colonial consolidation in return for the British support of the strengthened French position in East Central Europe. For the French the main concern was to weaken Germany by creating client states in Central and Eastern Europe and establishing a cordon sanitaire in this region to keep the Bolshevik germs from spreading to the rest of Europe.

In the face of these concrete objectives, the American delegation, including the Inquiry experts, were greatly disadvantaged. Furthermore, they lost Wilson's active engagement, and Secretary of State Robert Lansing was a weak link with very little understanding of European history beyond the English Channel. This meant that on the two key committees dealing with the future borders of Hungary the American members followed either the directives of the French diplomat Jules Cambont or of former premier André Tardieu. At the same time they were also bombarded by the anti-Hungarian pre-war and wartime propaganda of R.W. Seton-Watson, Wickham Steed, the Czech duo of Eduard Benes and Tomas G. Masaryk, as well as their own Robert J. Kerner and Max Handman. In this context it is not surpising that Robert Lansing could come to the conclusion that "we" do not have to worry about defining the borders of Austria or Hungary, we should focus on the borders of our friends, and whatever is left will be the borders of our former enemies. With this type of extreme one-sidedness, it is a wonder that the totally anti-Wilsonian Slavic Corridor through Western Hungary and the Romanian demand for the Tisza as their Western border, were finally vetoed by the American delegates.

As we have seen, Tibor Glant's volume on Trianon and American perspectives also sheds light on three myths regarding America's role. The first myth was that the Inquiry molded United States wartime policy. This was debunked by simply indicating that the Fourteen Points preceded most of the work of the Inquiry. The second myth was that the Inquiry lacked real professional fact finders. The documents in the volume disprove this myth in part, insofar as some were well- 
Ludányi, Andrew. "Glant, Tibor, ed. 2020. Az Egyesült Államok útja Trianonhoz: Az Inquiry és Magyarország jövöje, 1917-1918, Források ('The Approach of the United States to Trianon: The Role of "Inquiry" in Defining Hungary’s Future, 1917-1918, Sources'). Trans. Gergely Máté Balogh Budapest: Bölcsészettudományi kutatóközpont, történettudományi intézet: 1-272.” Hungarian Cultural Studies. e-Journal of the American Hungarian Educators Association, Volume 14 (2021) DOI: 10.5195/ahea.2021.450

written policy papers. On the other hand, the papers of Robert J. Kerner and Max Handman were openly biased and favored anti-Hungarian decisions. Finally, the last myth was that the Americans were more pro-Hungarian than the other Entente powers. The overall record in the Inquiry documents does not support this. However, in relation to the American veto of the Tisza border with Romania and the rejection of the Slavic corridor through Western Hungary, we can say that on these two issues the Wilsonian principles prevailed.

Az Egyesült Államok útja Trianonhoz ['The Approach of the United States to Trianon'] should be on the book shelves of all serious twentieth-century scholars of Hungary and East Central Europe. Overall it is a good read and the editor, as well as Gergely Máté Balogh, should be credited for their fine Hungarian translation of the English language documents. 